\section{Academic staff and honorary members of the Institute}

\section{Academic staff and their research interests, 2000/2001}

\section{Barbara Adams}

Research Curator

Predynastic Egypt, especially Hierakonpolis; collections of the Petrie Museum of Egyptian Archaeology

\section{Neal Ascherson DLitt}

Lecturer (part time)

Archaeology and the media; Balkan archaeology; heritage studies

Sally-Ann Ashton PhD

Lecturer

Ptolemaic and Roman Egypt: sculpture, pottery, faience and terracottas

Elisabeth Bacus PhD

Lecturer

Archaeology of Southeast Asia; complex polities; ceramics; gender studies in archaeology

Luke Barber BSc

Research Fellow

Roman and post-medieval archaeology of Southeast England; medieval and postmedieval pottery and metalwork

\section{Martin Bridge $\mathrm{PhD}$}

Lecturer

Dendrochronological studies, northwest

Europe; analysis of tree rings for evidence of environmental changes

Cyprian Broodbank PhD

Lecturer

Aegean archaeology; Mediterranean dynamics; island archaeology; archaeological method and theory

Beverley Butler MA

Lecturer (hal ftime)

Cultural and critical histories of museums and heritage; theories of gender, identity and the past; Egyptian cultural heritage

James Conolly $\mathrm{PhD}$

Lecturer

Advanced computing applications in archaeology, databases and database theory; prehistory of Southwest Asia

Harriet Crawford PhD

Reader (hal f time)

Archaeology of Mesopotamia: prehistoric and Sumerian periods; archaeology of the Gulf; Dilmun seals, prehistory of Kuwait

Dominique de Moulins PhD

Senior Research Fellow

Archaeobotany of early agriculture in Southwest Asia; methodological aspects of British archaeobotany

\section{Peter Drewett PhD}

Reader

Landscape archaeology; later prehistory of Britain; ceramic-age societies in the Lesser Antilles, especially Barbados and the British Virgin Islands

\section{Charles Fitzgerald PhD}

Research Fellow

Human dental development, histology and morphology; dental reduction in Neanderthals and modern humans
Dorian Fuller PhD

\section{Lecturer}

Archaeobotany; early agriculture; archaeology of South Asia; Nubian archaeology

Andrew Garrard PhD

Lecturer

Early prehistory of Southwest Asia; behavioural changes relating to the origin of modern humans; origins of cultivation and pastoralism; faunal analysis

Elizabeth Graham PhD

Lecturer

Maya archaeology, conquest and contact; tropical urbanism; environmental impact; coastal adaptations; Belize, Cuba

James Graham-Campbell PhD

Professor

Early medieval period in northwest Europe; late Anglo-Saxon, Celtic and Viking art and artefacts

Ian Greig MA

Research Fellow

Development of field techniques; cultural resource management

Dafydd Griffiths PhD

Lecturer

Applications of techniques of physical science to archaeology; technology, provenance and deterioration of ceramics, glass and stone

Sue Hamilton PhD

Lecturer

European prehistory, particularly the first millennium BC; technological analysis of prehistoric pottery; landscape archaeology

Mark Hassall MA

Reader

Roman inscriptions, Roman army and Classical technology, particularly Greek and Roman warfare

Fekri Hassan PhD

Professor

Egyptian archaeology: predynastic period; archaeological theory; geoarchaeology; early religion and art

Jon Hather PhD

Lecturer

The archaeology of wood; palaeoenvironmental interpretation of non-cultural vegetative plant remains; anatomical and morphological techniques for identif ying root and tuber foods

Georgina Herrmann DPhil

Reader (half time)

Survey and excavation at ancient and medieval Merv, Turkmenistan; study of the ivories found at Assyrian Nimrud, Iraq, and of their Mediterranean parallels

Simon Hillson PhD

Reader

Bioarchaeology: dental studies, palaeohistology and palaeopathology in humans and other mammals

Andrea Horne MA

Research Fellow

Medieval art and iconography
Rosalind Janssen BA

Lecturer

Egyptian archaeology: textiles, history of collections

David Jeffreys PhD

Lecturer

Egyptian archaeology: survey, excavation and palaeoenvironments at ancient Memphis

Alan Johnston DPhil

Reader

Archaic Greece; Greek epigraphy and numismatics

Peter Jordan $\mathrm{PhD}$

Research Fellow

Ethnoarchaeology; Siberian hunter-fishergatherers

Suzanne Keene PhD

Senior Lecturer

Management and digitization of museum collections

Stuart Laidlaw BSc

Photographer

Recording of archaeological finds by digital imaging techniques and conventional photography

\section{Mark Lake PhD}

Lecturer

Study of cultural change through simulation modelling and GIS, with special reference to early hominid evolution and the use of space

Marcos Llobera PhD

Research Fellow

Theory and method of landscape research; GIS and landscape modelling with special reference to the western Mediterranean

Kris Lockyear PhD

Lecturer

Iron Age and Roman archaeology and numis matics of eastern Europe; nationalism; statistics and computing

Kevin MacDonald PhD

Lecturer

African archaeology: Holocene huntergatherer and agropastoral societies in West Africa, the African diaspora; origins of social complexity and urbanism; history of archaeology

\section{Sally MacDonald BA}

Museum manager

Museum management, marketing and outreach

Richard Macphail PhD

Senior Research Fellow

Archaeological soil science, especially the application of micromorphological techniques

\section{David Martin}

Research Fellow

Medieval and post-medieval building traditions in Southeast England

Louise Martin PhD

Lecturer

Vertebrate zooarchaeology; hunting and herding in prehistoric Southwest Asia; animal behaviour and ecology

Sarah Mason $\mathrm{PhD}$

Research Fellow (part time)

Archaeobotany of European hunter-gatherers and comparative ethnobotany of wild plant use in East Asia and North America 
James McGlade PhD

Principal Research Fellow

Iberian and Mediterranean prehistory;

archaeological theory; modelling complex

social and natural systems using GIS and

simulation

Paulette McManus PhD

Lecturer (half time)

Museum visitor studies; impact of heritage sites on landscape

\section{John Merkel PhD}

\section{Lecturer}

Archaeometallurgy: conservation of metal artefacts; early metallurgical processes and sites in the Near East, Europe and South America

Nick Merriman PhD

Reader

Cultural heritage; museums and the public; the archaeology of London

Gustav Milne MPhil

Lecturer (part time)

Archaeology of Roman and medieval Lon-

don; maritime archaeology, including intertidal zone survey

\section{Koji Mizoguchi PhD}

Lecturer

Japanese prehistory, especially the Yayoi period; mortuary practices; archaeological theory

\section{Norah Moloney PhD}

College Teacher

Palaeolithic archaeology of Europe and

Southwest Asia; lithic analysis

\section{Vivek Nanda PhD}

Lecturer

Indian art, archaeology and heritage; architectural history; urbanism and ritual landscapes; religion and pilgrimage; building conservation

\section{José Oliver PhD}

\section{Lecturer}

Latin American archaeology: chief dom societies in lowland South America and the Caribbean, especially Puerto Rico; symbolism of ceremonial centres

Clive Orton MA

Reader

Application of statistical methods and computers to archaeology; spatial analysis; quantification of assemblages of pottery

Gaetano Palumbo PhD

Senior Lecturer

Management and conservation of archaeological sites; documentation of cultural heritage; GIS; archaeology of the southern Levant; pastoral nomadism

\section{Simon Parfitt MSc}

Senior Research Fellow

Analysis of animal remains from British Palaeolithic sites, especially Boxgrove, Sussex

Matthew Pope BSc

Research Fellow

Analysis of stone-tool assemblages from British Lower Palaeolithic sites, especially Boxgrove. Sussex

Clifford Price PhD

\section{Professor}

Conservation of sites and monuments; conservation of stone; mechanisms and prevention of salt damage in porous materials; control of the museum environment

Elizabeth Pye MA

Senior Lecturer

Conservation method and ethics; conservation of wall paintings and of organic, particularly ethnographic, materials

Stephen Quirke PhD

Lecturer and Assistant Curator

Egyptology: literacy, material culture and vocabulary; history of collections

Thilo Rehren Dr-Ing habil

Professor

Archaeological high-temperature materials and technologies; Bronze Age to earlymodern period in Eurasia, Africa and South America

\section{Andrew Reid PhD}

Lecturer

Archaeology of eastern Africa: complex societies, herd management and butchery practices

Mark Roberts BA

Principal Research Fellow

Palaeolithic archaeology of southern Britain; excavation of the Lower Palaeolithic site of Boxgrove, Sussex

Arlene Rosen PhD

Lecturer

Geoarchaeology; phytolith analysis; climate and culture; Near Eastern Neolithic and Early Bronze Age archaeology; prehistory of Central Asia

David Rudling MA

Senior Research Fellow

Iron Age and Romano-British settlement in Southeast England; Roman and medieval numismatics

Delwen Samuel PhD

Wellcome Bioarchaeological Research

Fellow

Microscopv of ancient food remains; technology of producing cereal and other plant foods; archaeobotany of Egypt and Southwest Asia

Tim Schadla-Hall MA

Reader

Public archaeology, museum development, heritage industry and cultural economics; early Mesolithic of northwest Europe; landscape archaeology

\section{Stephen Shennan PhD}

Professor

Archaeological theorv; quantitative and computer applications; Neolithic and Bronze Age of Europe

\section{Aaron Shugar PhD}

Research Fellow

Chalcolithic and Bronze Age metallurgy in the Levant; experimental archaeology of

bronze casting and glass making; instrumental analysis of archaeological glass, cast iron and arsenical copper

\section{Jane Sidell MSc}

Senior Research Fellow

Environmental archaeology including sealevel change; archaeology of London

Bill Sillar PhD

Lecturer

Andean archaeology; ethnoarchaeology; comparative analysis of ceramics, material culture and technology
Rachael Sparks PhD

Curator

Cultural interaction between the Levant and Egypt during the Bronze and Iron Ages; stonevessel trade and manufacture

Dean Sully BSc

Lecturer

Conservation of organic materials

John Tait DPhil

Professor

Egyptian social history, language and documents; the Saqqara and the Carlsberg Papyri projects

Jeremy Tanner PhD

Lecturer

Greek and Roman art and architecture; sociology of art; art theory and criticism; comparative historical studies of art and religion

Ken Thomas PhD

Reader

Reconstruction of past human environments; palaeoecological theory; Bannu archaeological project, Pakistan

\section{Christopher Tilley PhD}

Professor

Archaeological theory; Neolithic and Bronze Age of northwest Europe; systems of visual representation; ethnoarchaeology

\section{Kathryn Tubb BA}

Lecturer

Conservation treatments for Neolithic limeplaster statues from 'Ain Ghazal, Jordan; conservation of other inorganic materials; ethics in cultural heritage

Peter Ucko PhD

Professor

Prehistoric art and religion; the comparative study of material culture; education about the past

\section{Martin Welch DPhil}

Senior Lecturer (half time)

Early Anglo-Saxon archaeology; Europe in the migration, Merovingian and early Carolingian periods

Ruth Whitehouse PhD

Reader

Prehistory of Italy and the western Mediterranean; ritual and religion in prehistory; gender studies in prehistory

Todd Whitelaw PhD

Reader

Aegean archaeology; ethnoarchaeology:

landscape archaeology; ceramics; quantitative data analysis; archaeological method and theory

John Wilkes PhD

Professor

Roman provinces: Britain, Danube lands, North Africa; Roman inscriptions and topography

\section{Katherine Wright PhD}

Lecturer

Archaeology of the Levant and southern Anatolia; trade and early urbanism; food processing and prehistoric diet; anthropological approaches to archaeology 


\section{Academic staff $\mathbf{1 9 9 9 / 2 0 0 0}$}

\section{RESIGNATIONS}

Dr Val Kirby

Dr Andrew Reynolds

Dr Nicholas Stanley-Price

\section{CONTRACT EXPIRED}

Susanne Gilbert

\section{Honorary members, 2000/2001}

VISITING PROFESSORS

Hans-Gert Bachmann PhD

James Charles ScD

Henry Cleere DLitt OBE

Anthony Constantinides $\mathrm{PhD}$

Beatrice de Cardi OBE

Margaret Drower MBE

Lisa Fentress DPhil

Ian Freestone $\mathrm{PhD}$

Edward Hall DPhil, Hon FBA

David Hawkins MA

Gordon Hillman BSc

John Mann PhD

Vincent Pigott PhD

Beno Rothenberg PhD

Tim Shaw PhD (hon.)

Geoffrey Wainwright PhD, MBE

Sir David Wilson LittD, FBA

Daniel Zohary PhD

\section{RESEARCH FELLOWS}

Hala Barakat PhD

Pierre Brun MA

David Buckley BSc

John Casey BA

Sarah Clackson PhD

Helen Clarke PhD

Peter Connolly

Jane Cronyn MSc

Susan Davies MA

Claude Doumet PhD

Neil Faulkner PhD

Lamia al Gailani Werr PhD

David Gaimster PhD

Caroline Grigson PhD

Eric Harris DSc

Edward Herring PhD

Jacob Janssen DPhil

Ann Kendall PhD OBE

Olga Krzyszkowska PhD

Paul Lane PhD

Cary Martin PhD

Anthony Mills BA

Mohammed Mohammed BA

Dominic Montserrat PhD

David Morgan Evans PhD

Mark Nesbitt PhD

Andrew Oddy DSc

Peter Parr MA

David Prince $\mathrm{PhD}$

Nicholas Reeves PhD

Peter Reynolds PhD

Margaret Roxan PhD

Julia Samson

Nigel Seeley PhD

Mark Spiegelman PhD

Eric Uphill MA

John Watson PhD

Leslie Webster BA

Xing Wen PhD

\section{LECTURERS}

Adrian Babbidge MA

Ann Butler PhD

Patrick Fallon PhD

Andrew George PhD

Roger Matthews PhD
Anthony Waldron $\mathrm{PhD}$

Patricia Wiltshire BSc

RESEARCH ASSISTANTS

Robert Carter PhD

Evangelia Kiriatzi BA

Virginia Mathias BA

Craig Merideth PhD

Margaret Serpico PhD

\section{Visiting scholars from overseas}

In 2000/2001, scholars from Argentina, Bangladesh, India, Israel, Nigeria, Pakistan, Sri Lanka and Tanzania undertook research at the Institute.

\section{PhDs awarded, 2000}

Marlena Antczak

"Idols" in exile: making sense of prehistoric human pottery figurines from Dos Mosquises island, Los Roques archipelago, Venezuela

Polydora Baker

Society and economy in northern Italy in the early medieval period (c. 6th-11th centuries $A D)$ : a zooarchaeological study

Dido Clark

A methodological examination of as pects of chronological and social analysis of early Anglo-Saxon cemeteries with particular reference to cemetery 1 at Mucking, Essex

Paul Collins

Social ideology and the Uruk phenomenon

Rhodri Gardner

Bone diagenesis: taphonomy in archaeologi cal bone and its relationship with the survival of ancient DNA

Helen Haines

Intra-site obsidian distribution and consumption patterns in nort hern Belize and the northeastern Peten

Marcello Mannino

Marine molluscs and human palaeoecology: a case study of the intertidal gastropod Monodonta lineata (Da Costa)

\section{Allan Moore}

Micro-settlement analysis in the Belize River valley: archaeological investigations at Atalaya, a formal patio group at Baking Pot

David Perkins

A gateway island: an exploration o fevidence for the existence of a cultural focus in the form of a "gateway community" in the Isle of Thanet during the Bronze and Early and Middle Iron Ages

Ruth Prior

Early historic ceramics from Tra Kieu, central Vietnam: typological and petrographic characterization

Gabrielle Puschnigg

A diachronic and stylistic assessment of the ceramic evidence from Sasanian Merv

Pamela Rumball Rogers

Maritime adaptation in the prehistory of the Pearl River estuary, China

Denise Studart

The perceptions and behaviour of children and their families in child-orientated museum exhibitions
Gabor Thomas

A new surveyo flate Anglo-Saxon and Viking Age strap ends from Britain

Renata Walicka Zeh

Building practice and cultural space among the Bamara, Senvto and Bozo of Mali: an eth noarchaeological study

Quanyu Wang

The metalworking technology and the deterioration of Jin bronzes from the TianmaQucun site, Shanxi, China

Sylvia Warman

Morphometric investigation of dental variation to examine genetic relationships between pig populations

Alexander Wasse

The development of goat and sheep herding during the Levantine Neolithic

\section{Registered research} students, 2000/2001

Hamdi Abd El-Moniem

Anthropological investigations of prehistoric rock art in Africa

Marc Abramiuk

Mathematical modelling of social phenomena in complex societies

Haya Al-Thani

Dilmun glyptic: the indigenous stylistic elements and their implications for social and economic life in early Dilmun

Seona Anderson

A social history of wild plant use in indigenous communities of the Russian Far East

Despina Angelakou

Hellenistic relief sculpture from northern Greece

Noemie Arazi

Spatial analyses at the West African town of Dia, Mali

Zaki Aslan

Conservation, architecture and archaeology: protective structures for the conservation and presentation of archaeological sites

Eleni Asouti

Charcoal analysis from the Neolithic sites of Catalhöviik and Pinarbasi in south-central Anatolia, Turkey

Phil Austin

Taphonomy of wood charcoal samples

Louise Bacon

A technical and historical study of certain London brass wind instruments and their makers

Nicholas Bateman

Roman amphitheatres in their social, economic and physical context

Alexandra Bayliss

Validating classical multivariate models in archaeology: English medieval bell founding as a case study

Christopher Bayliss

A structural history of regionalization in the eastern Harappan civilization 
Adnan Baysal

A contextual analysis offood-processing and related artefacts in Neolithic central Anatolia

Joy Belmonte

The archaeology of early colonialism in the Philippines

Elizabeth Bettles

Phoenician amphorae of the Persian period: studies in provenance, economic complexity and control

Andrew Bevan

V'alue regimes in the eastern Mediterranean Bronze Age: an analysis through stone vessels

Elizabeth Bloxam

The organization, transportation and logistics of hard-stone quarrying in the Egyptian Old Kingdom: a comparative study

Stuart Brookes

Landscapes, settlements and exchange: a reassessment of Anglo-Saxon economics and social change $A D 400-1100$, with special reference to Kent

Michael Burns

Military equipment of the Samnites

Beverley Butler

The Alexandrian Mouseion/Library: an investigation of discourses of origins and revivalisms with special reference to the Old Museology and to contemporary revival projects in Alexandria, Egypt

Richard Carter

The demography of red deer and roe deerand their implications for the Mesolithic of northwest Europe

Kuang-Jen Chang

Political economics of trade ceramics in late medieval South China and proto-historic Philippines $c .12$ th to 16 th centuries $A D$

David Clark

Space-syntax analysis of early Christian churches

Vathalie Cohen

Early medieval settlements and riverine topography

Martin Comey

Medieval stave-built wooden vessels in Ireland and Russia

Marion Cutting

Village and domestic architecture in Anatolia c. 8000-5500 BC: shelter, subsistence and the changing use of space

Chris Davenport

The pre-Roman Iron Age in the Solent area

Helen Dawson

Comparative cultural trajectories in the western and central Mediterranean islands from the Neolithic to the Iron Age

Aloisia de Trafford

The human body in the Pyramid Texts: a schema-theory approach

Christina Deter

Dental wear patterns ofhunter-gatherers and agriculturists of the Epi-Palaeolithic and Neolithic of the Levant

\section{Carol Downer}

The martyrdom of St Pteleme (Coptic Manuscript M581, Pierpont Morgan Library): edition and commentary
Nadia Durrani

Evidence for the pre-Islamic occupation of

the Tihamah Plain and Red Sea coast of Yemen

Kevan Edinborough

Comparative study of bow-and-arrow technology in the et hnographic and archaeological record

\section{Maria Empis}

The application of geographic information systems to the study of the Roman civitas of Eburobrittium, Portugal

Maria Luz Endere

Management of archaeological sites and the public in Argentina

Ann Feuerbach

Evidence for the organization and production of crucible steel in early Islamic Central Asia

Alvaro Figueiredo

The epidemiology of Roman populations in Portugal and the Arab Republic of Egypt

Agapi Filini

The presence of Teotihuacan in the north of the state of Michoacan, Mexico, AD 250-650

Danae Fiore

Body painting in Tierra del Fuego: the power of images in the uttermost part of the world

Andrew Gardner

Military and civilian in late Roman Britain an archaeology of social identity

Myrto Georgakopoulou

Early Cycladic metallurgy

Amanda Giles

Sexuality, power and gender: Darwinian frameworks for the study ofgender dynamics in the archaeological record

\section{Grant Gilmore}

A comparative analysis of slave culture and economy on the island of St Eustatius, Netherlands Antilles

Stavroula Golfomitsou

Corrosion inhibitors used in the treatment of archaeological copper and copper-alloy artefacts: their current limitations and potential improvement

Angus Graham

Ports and harbours in Pharaonic Egypt: an investigation into their location, physical nature and the activities and people therein

\section{Reuben Grima}

Perceptions and management of archaeological landscapes

Fiona Handley

Slavery for sale: the heritage dynamics of historic slavery sites in West Africa and Louisiana, USA

Susan Harrington

Gender and craft production in early AngloSaxon England, with particular reference to the kingdom of Kent

Jonathan Hassell

Ritual aromas: the cuboid incense-burning altar of pre-Islamic southern Arabia

Fiona Haughey

Prehistory within a difficult landscape: the

Mesolithic and Neolithic of the urban tidal Thames
Caroline Hebron

The evidence for work-related injuries and diseases in ancient Egypt

Lisa Hilborn

Lithic studies in the May Lowlands: expedient tool technology from Tipu, Belize

Mary Horbury

Egyptian self-definition and concepts of the "other" in the New Kingdom and the Coptic period

Valasia Isaakidou

The economic and cultural roles of animals on Neolithic and Bronze Age Crete: a zooarchaeological analysis of faunal assemblages from pre-palatial Knossos and comparative sites on Crete

Mutsumi Izeki

Symbolism of Xihuitl in the Postclassic Nahua culture

Alejandro Jimenez-Serrano

Kingship and festivals in the Late Pred ynastic and Early Dynastic periods

Tomoko Kanoshima

Information communication technology for aesthetic education in art museums and galleries

\section{Quetta Kaye}

Ritual drug use and the social context of power in the prehistoric Caribbean, with Cuba as its specific focus

Cornelia Kleinitz

Rock art in sub-Saharan West Africa: a comparative study of motifs in the Upper and Middle Niger regions of Mali

Vassiliki Konortou

Greek numismatics: legal aspects of Greek coinage

Vassiliki Kyriakopoulou

Popular interpretation of Bronze Age sites in Greece

Sophia Labadi

The World Heritage Site list and politically incorrect heritage: the case of industrial archaeology

Konstantina Liwieratos

Managing cultural heritage for conservation and presentation: the case of Mani, southern Peloponnese

Serena Love

The ancient Egyptian Old Kingdom capital: an investigation

Isabel Medina-Gonzalez

Nineteenth-century three-dimensional representations of Mesoamerica: exhibitions of Mesoamerican cultures in Britain, the United States, France and Mexico, 1800-1900

Tomas Mendizabal

The construction oftaxonomical and analytical time in Panama Viejo, Panama

Luisa Mengoni

Rock-cut burials in Sichuan during the Han dynasty: investigation of their social, ideological and symbolic significance

Maria Mina

Gender in the Neolithic of Greece, the Balkans and Anatolia

Hiromi Miyauchi

The birth and development of department stores' exhibitionary spaces and museums: 
their definition as institutions and their role in the Japanese museum context

\section{Andrew Monson}

Ptolemaic kingship and the Egyptian temples Justin Morris

An examination of the spatial and temporal variation of lithic technologv from the Neolithic to the Early Bronze Age in Pakistan

\section{Carrie Murray}

Defining the relationship between religious and social complexity in Etruria, from the final Bronze Age to the Archaic period

Shin'ichi Nishiyama

At the fringe of the empire: sociopolitical development of Iron Age settlements in the northwestern Levant

\section{Lawrence Owens}

Biological perspectives on the human colonization of the Canary Islands

\section{Catherine Pearson}

A history of museums in World War II

Mariana Perez-Sala

The role of glas s in the western Roman empire in the late first and early second centuries $A D$

Marilena Pollicino

The contingent valuation method as a tool with which to manage cultural heritage

Alexandra Porter

Patterns of production and circulation in southwestern Arabia and beyond in the first millennium $B C$ : the evidence of amphorae

Petros Prokos

The deterioration process of the wallpaintings of Delos

Lucinda Reeves

Bronze Age Aegean and Anatolian metal vessels: technology, style and intercraft influence

\section{Patricia Reid}

An investigation of perceptions of the human body through a study of stylistic variability in footwear in northern Europe, AD 900-1150

\section{Muria Roberts}

Human-animal communications in the zoo context

\section{Gary Robinson}

The spatial and social production of the later prehistoric landscape of the Isles of Scilly

Joanne Rowland

Social transformation in the Nile Delta from the Terminal Predynastic to the Early Dynastic period: a comparative study

\section{Mark Sandy}

Ethnobotany and archaeobotany of Pandanus in the Papua New Guinea Highlands

\section{Alison Sawdy}

The kinetics of salt weathering of porous materials: stone and wall paintings

Jennifer Scarlin

Postclassic Lamanai iconography

Sophie Seel

The archaeology of East London's prehistoric woodlands

Rula Shafiq

Diet, healt $h$ and nomad-sedentary interaction in the Jordan Valley: the skeletal assemblages of Jericho and Tell es-Sa'idiyeh
Theo Skinner

Investigations into the water content of the cellwallo f waterlogged archaeological wood and its replacement with water-soluble bulking agents

Michela Spataro

Production and circulation of Early and Middle Neolithic pottery in the Adriatic

Fay Stevens

A contextualized studyof the land scape loca tions ofdeliberate depositions of Bronze Age metalwork in watery contexts in southwestern Britain

\section{Delphine Stork}

Towards a new perspective on the Neolithic of the Bodensee: subsistence and settlement in the context of environmental change

Robert Symmons

A taphonomic analysis of the faunal remains from Çatalhöyük, Turkey

\section{Jigen Tang}

The social organization of Late Shang China: a mortuary perspective

Steve Townend

An early Heideggerian analytic of the activity of reconstructing the southern British Iron Age round house

Kalliopi Vacharopoulou

Conservation of archaeological sites

Sven van Lokeren

A reconstruction of the $L B A$ copper-smelting industry in Cyprus and an evaluation of its implications for industrial organization

Maria Ines Velarde

Characterization of ornamental metal objects from nort h-coast Peru during the Early Intermediate period

Liz Walder

Controversial issues interpreted in museum exhibitions and displays

Helen Wang

Money on the Silk Road: the pre-Islamic coins in the Stein Collection from Chinese Central Asia in the light of recent archaeology in Zinjiang

Derek Watson

The transition to food production in mid-second millennium BC Ghana

Glenn Wharton

The conservation of contested cultural sites

Michele Wollstonecroft

Post-harvest: the effects of innovations in plant-food processing methods and their implications for resource intensification during the late Pleistocene in Southwest Asia

Jay Woodhouse

Bridging the gap: the origins and effects of metallurgy in Ghana

Ching-Shan Yang

Public willingness to pay for museums: an economic investigation of museums in Taiwan

Jacqueline Zak

Frameworks for computer-supported collaboration in archaeology and related disciplines

\section{PIA}

Papers from the Institute of Archaeology is produced annually by postgraduates. The contents of previous volumes were listed in AI 1997/98 (vols 1-8), AI 1998/99 (vol. 9) and $A I$ 1999/2000 (vol. 10). Volume 11, 2000, contains FORUM b y James P. Mower (Trench warfare? Archaeologists battle it out, with a reply by Mick Aston); an INTERVIEW with Dr Robert Anderson, Director of the British Museum; RESEARCH PAPERS by Fiona Handley (Not just add-gender-andstir: feminist archaeolog $y$ and the use of feminist and evolutionary biological approaches to patriarchy), Geoffrey J. Tassie (Bulls, hair and teknu: an enigmatic Egyptian custom revisited (Burial of the black hairs), Ann Brysbaert (The role of a field laboratory in the preliminary study of Bronze Age plaster fin ds from Palaikastro, east Crete) and Serena Love (A peripatetic Old Kingdom centre: a Fourth Dynasty model of Giza); FIELDIVORK REPORTS by Stuart Brookes (The Kent Anglo-Saxon emporia project (KASEP)), Sue Harrington (Fieldwork report of the ASKED project 1999-2000), R. Grant Gilmore III (Slave site archaeology on St Eustatius, Netherlands Antilles) and Cornelia Kleinitz (Tracing a West African past: rock art recording in Sub-Saharan Mali); CONFERENCE REVIEIVS by Julie Eklund of "Human remains: conservation, retrieval and analysis", Colonial Williamsburg, November 1999, Fay Stevens of "Neolithic archaeology in the intertidal zone of rivers and estuaries", Neolithic Studies Group autumn meeting, Society of Antiquaries of London, November 1999, Quetta Kay of "New approaches to the archaeology of art, religion and folklore: a permeability of boundaries?", University of Southampton, December 1999, G. J. Tassie, J. M. Rowland and A. de Trafford of "The 8th International Congress of Egyptologists", Cairo, March-April 2000, A. Brysbaert and A. Lindenlauf of "Colour in ancient Greece: international conference on the role of colour in ancient Greek art and architecture, 700-31 BC", Thessaloniki, April 2000 and J. Mower and G. J. Tassie on "Egyptian human remains: retrieval, conservation and analysis", Qantara, Egypt, A pril 2000; BOOK REVIEWS by Steve Townend of P. G. Stone \& P. G. Planel (eds) 1999, The constructed past: experimental archaeologv, education and the public and by Gillian Hawkes of P. S. Wells 1999, $T$ he barbarians speak: how the conquered peoples shaped Roman Europe; ABSTRACTS of recently passed PhD theses; notes to contributors.

Volume 11 and previous volumes (except 1 and 4) can be obtained from the Editors, PIA, Institute of Archaeology, University College London, 31-34 Gordon Square, London WC1H OPY, England; Email: tcrnpia@ucl.ac.uk; Website: http:// www.ucl.ac.uk/archaeology/pia. 